C. J. Northrup

Sandia Laboratories

Albuquerque, NM 87175

505/264-5650

For general information concerning the annual meeting contact:

Materials Research Society Secretariat Ernest M. Hawk, Executive Secretary 102C Materials Research Laboratory University Park, PA 16802

814/865-3424

\section{VON HIPPEL AWARD OF THE MATERIALS RESEARCH SOCIETY - NOMINATIONS}

Nominations are invited for the Von Hippel Award of the Materials Research Society. This prize recognizes outstanding practitioners of the multi-disciplinary endeavor of materials research. It is intended to honor pioneers who have shaped our understanding of the mutual enhancement of the various disciplines engaged in the study of materials. The prize was named after its first recipient, Arthur Von Hippel, emeritus professor at the Massachusetts Institute of Technology. Other recipients include Dr. William O. Baker and Professor David Turnbull. The prize consists of $\$ 1000$ and a decorative ruby crystal. Nominations with supporting documentation should be sent before September 1, 1980 to the Chairman of the Awards Committee, Dr. Rudolf J. H. Voorhoeve, c/o Celanese Corp., Summit, N. J. 07901.

\section{ANNUAL MEETING DATE SET}

The 1981 Annual Meeting will be held in Boston, Massachusetts, at the Copley Plaza Hotel from November 15 to November 20. The Lenox Hotel will serve as additional accommodation for attendees.

Program Chairmen for this meeting will be H. J. Leamy (Bell Labs 201 5822628), P. A. Montano (West Virginia
University (304 293-5769), and C. W. White (Oak Ridge, 615 574-6295).

The Chairmen held a meeting at Oak Ridge National Laboratory on June 10 to discuss the 1981 program. Several new developments were proposed and a tentative list of symposia will be given in the next newsletter. The Chairmen welcome any suggestions for new symposia topics. 